University of Maryland Francis King Carey School of Law

DigitalCommons@UM Carey Law

\title{
$5-2011$
}

\section{Opening the Industry Playbook: Myths and Truths in the Debate over BPA Regulation}

Thomas McGarity

Rena I. Steinzor

University of Maryland School of Law, rsteinzor@law.umaryland.edu

Matthew Shudtz

Lena Pons

Follow this and additional works at: https://digitalcommons.law.umaryland.edu/fac_pubs

Part of the Environmental Law Commons, and the Environmental Public Health Commons

\section{Digital Commons Citation}

Center for Progressive Reform White Paper no. 1107

This Working Paper is brought to you for free and open access by the Francis King Carey School of Law Faculty at DigitalCommons@UM Carey Law. It has been accepted for inclusion in Faculty Scholarship by an authorized administrator of DigitalCommons@UM Carey Law. For more information, please contact smccarty@law.umaryland.edu. 
Opening

the Industry Playbook: Myths and Truths in the Debate Over BPA Regulation

By CPR Member Scholars Thomas McGarity and Rena Steinzor, CPR Senior Policy Analyst Matthew Shudtz, and CPR Policy Analyst Lena Pons

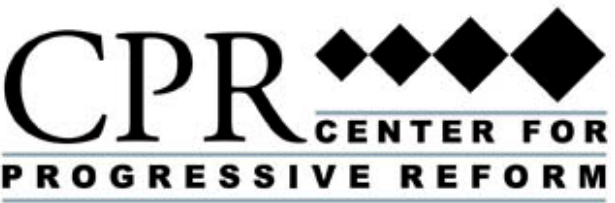




\section{CENTER FOR}

PROGRESSIVE REFORM

WHITE PAPER \#1107

May 2011

\section{Acknowledgments}

The Center for

Progressive Reform

is grateful to the

Johnson Family

Foundation, the

John Merck Fund,

and the Passport

Foundation for its

generous support

of CPR's work.

\section{About the Center for Progressive Reform}

Founded in 2002, the Center for Progressive Reform is a 501(c)(3) nonprofit research and educational organization comprising a network of scholars across the nation dedicated to protecting health, safety, and the environment through analysis and commentary. CPR believes sensible safeguards in these areas serve important shared values, including doing the best we can to prevent harm to people and the environment, distributing environmental harms and benefits fairly, and protecting the earth for future generations. CPR rejects the view that the economic efficiency of private markets should be the only value used to guide government action. Rather, CPR supports thoughtful government action and reform to advance the well-being of human life and the environment. Additionally, CPR believes people play a crucial role in ensuring both private and public sector decisions that result in improved protection of consumers, public health and safety, and the environment. Accordingly, CPR supports ready public access to the courts, enhanced public participation, and improved public access to information. CPR is grateful to the Deer Creek Foundation and the Bauman Foundation for their generous support of its work in general.

This white paper is a collaborative effort of the following Member Scholars and staff of the Center for Progressive Reform: Thomas McGarity holds the Joe R. and Teresa Lozano Long Endowed Chair in Administrative Law the the University of Texas--Austin, is a member of the Board of Directors of the Center for Progressive Reform, and is the immediate past president of the organization; Rena Steinzor is a Professor at the University of Maryland School of Law and the President of the Center for Progressive Reform; Matthew Shudtz is a Senior Policy Analyst at the Center for Progressive Reform; and Lena Pons is a Policy Analyst at the Center for Progressive Reform.

For more information about the authors, see page 19.

www.progressivereform.org

For media inquiries, contact Matthew Freeman at mfreeman@progressivereform.org or Ben Somberg at bsomberg@progressivereform.org.

For general information, email info@progressivereform.org.

(C) 2011 Center for Progressive Reform. 


\section{Executive Summary}

Of all the scientific discoveries regarding the subtle effects of pollution on public health, few are more fundamentally troubling than the revelation that synthetic "endocrine disrupters," ingested at very low doses, can turn males into females, disrupt fertility, and even render living things hermaphroditic. These chemicals are in common use in the American marketplace, deployed as pesticides (DDT and atrazine), oral contraceptives, and building blocks for polycarbonate plastics and epoxy resins (bisphenol-A, or BPA). By mimicking the effect of critical hormones like estrogen, they can trigger biological responses at the wrong time or in damaging ways.

Scientists have known about BPA's endocrine-disrupting potential since the 1930s, but what has only recently come into focus is its tendency to leach out of plastics and cause adverse effects in animals. Its leaching effect was not fully understood until strange results occurred in two labs at opposite ends of the country circa $1989 .{ }^{1}$ In one, a team at Tufts Medical School in Boston, Massachusetts was trying to find a natural inhibitor to the rapid growth of breast cancer cells, while in the other, a team at Stanford University School of Medicine in Palo Alto, California was researching the reactions of estrogen-sensitive cells. Tufts researchers Ana Soto and Carlos Sonnenschein discovered to their dismay that cells they did not expect to grow were multiplying rapidly, for no apparent reason. Repeating their experiments over and over again for several months, they finally isolated the problem as a change in the components of their laboratory equipment, specifically the manufacturer's addition of alkylphenol polyethoxylates containing

\section{Contents}

Executive Summary …………………………....1

Introduction ………………………………….... 4

The Myth of a Scientific Consensus on Safety......... 5

The Good Laboratory Practices Myth ...................... 7

The Exposure and Metabolism Myths................... 8

Economic Myths ................................................. 10

The Myth of the Patchwork of Regulations.......... 12

Working Toward a Solution:

Broadening Narrow Jurisdictional Roles................ 14

Conclusion ............................................................ 16

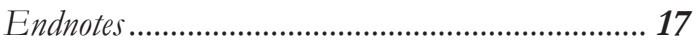

About the Authors ............................................... 19

BPA to the plastic in the centrifuge tubes where they had stored blood serum used in their experiments. In a new line of experiments, they discovered that injections of the chemical into rats confirmed the chemical's estrogen-mimicking capacity. The Stanford scientist, David Feldman, similarly discovered that BPA in polycarbonate lab flasks used to sterilize water in his experiments was mimicking estrogen and causing abnormal cell growth.

Two decades later a substantial body of research suggests that, at very low doses, BPA causes reproductive disruption in rats and, most likely, in humans. The substance is also ubiquitous, with one study showing its presence in the urine of 95 percent of adults who participated in a Centers for Disease Control screening program called the National Health and Nutrition Examination Survey (NHANES). ${ }^{2}$ This research makes a compelling case that, in accordance with the precautionary principle embedded throughout American public health law, BPA and other synthetic endocrine-disrupting chemicals should be removed from consumer products, especially those used by women who may become or are pregnant, and their young babies post-delivery. 
Despite the mounting evidence of adverse health effects, plastics manufacturers are still doing their best to avoid or obscure these results and have launched an aggressive campaign to block federal agencies' efforts to regulate BPA. In fighting BPA regulation, the plastics industry is resorting to the same tactics used in the past by the manufacturers of cigarettes, automobiles, and pesticides, as well as many other industries determined to avoid government regulation: influence and distort the findings of federal science panels, attack academic science, publish and underwrite biased scientific research, and promote misleading information about the costs of regulation. ${ }^{3}$

Their core mission in each of these efforts is to undermine the validity of the key hypothesis of endocrinology - that the timing of hormone exposure is at least as critical as the level of exposure. Because synthetic chemicals that mimic estrogen can disrupt normal biological processes at very low doses, they must be evaluated under a different paradigm and with a different set of assumptions than those traditionally applied to the better-characterized problem of chemical carcinogens. With chemical carcinogens, the axiom is that the "dose makes the poison" or, in other words, the greater the chemical exposure, the greater the cancer risk. With endocrine disrupters, irreversible damage can occur at very low doses, not necessarily predictable by higher dose observations.

This paper reviews the major arguments advanced by the plastics industry in debates before federal agencies, state legislatures, and in any publication that will publish such self-interested speculation. ${ }^{4}$ In response to these myths — about the science, economics, and law related to BPA regulation - the paper explains what the scientific and policy literature actually says about BPA exposure.

The myth of a scientific consensus on safety: Industry advocates commonly assert that scientists concur that BPA is safe. In fact, scientists agree that BPA is a known endocrine disruptor and that it is therefore unsafe.

The Good Laboratory Practices myth: Industry activists argue that regulatory agencies should disregard studies that do not comply with FDA's Good Laboratory Practices standard, including many studies that exhibit a link between lowdose BPA exposure and adverse health effects. In so doing, they misapply the GLP standard, which is focused primarily on recordkeeping and maintenance requirements, and is therefore not the best measure of a particular study's scientific validity. It is a mistake to ignore the pioneering work that meets other standards of quality, like robust peer review.

The exposure and metabolism myths: BPA manufacturers would have us believe that the risk of adverse effects from BPA exposure is insignificant because typical human exposures are low and the chemical is readily metabolized into non-endocrine-disrupting forms. However, strong research shows that BPA's ubiquity leads to such frequent doses that even healthy adults cannot metabolize all of the chemical in their bodies. Fetuses and infants, with their less developed metabolic systems, are at particular risk of adverse health effects. 
The economic myths: BPA manufacturers maintain that the chemical is a key ingredient in safe food packaging, one that cannot be replaced with economical alternatives. In fact, numerous canned food companies have replaced BPA without significant cost problems, and BPA bans in Japan, China, and in various states in the U.S. have spurred innovation.

The myth of "patchwork" regulation: The BPA-manufacturing industry complains that lack of uniformity in state-level regulations increases the costs of producing, distributing, and marketing their products. Although a growing coterie of states has banned the sale of certain products with BPA, the truth is that non-regulation of BPA is the norm across the United States. The real purpose of propagating this myth is to move the regulatory debate to the federal level, where large manufacturers' advocates often have a stronger voice than their public interest counterparts.

\section{Conclusion and Recommendations}

Addressing toxic chemical risks at the federal level can produce significant public health benefits. Achieving those benefits depends on federal agencies' ability to develop a plan to coordinate information-gathering and regulatory activities to create a consistent, precautionary approach to regulation. In the case of BPA, it appears that the Environmental Protection Agency (EPA), Food and Drug Administration (FDA), and the National Institutes of Environmental Health Sciences (NIEHS) and Occupational Safety and Health (NIOSH) are starting to coordinate their work, but that more could and should be done. Congress could improve the federal approach to toxics regulations by affirmatively empowering agencies like the EPA, FDA, CPSC and OSHA to regulate endocrine-disrupting compounds. 


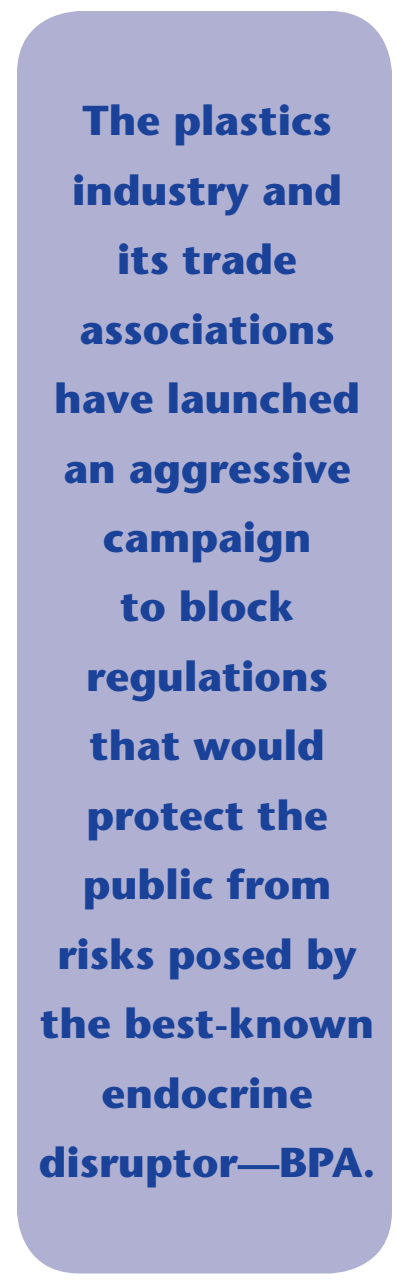

\section{Introduction}

The body's endocrine glands do their work of directing various bodily responses by secreting hormones into the bloodstream. Glands distributed around the body play a major role in regulating metabolism, various reproductive functions, growth, and more. The disruption of these sensitive systems is extraordinarily time-sensitive. If a synthetic chemical mimicking a critical hormone like estrogen, but also triggering destructive rather than natural effects, enters the body while a fetus is developing in utero, it can cause irrevocable disruption of the human reproductive system.

The plastics industry and its trade associations have launched an aggressive campaign to block regulations that would protect the public from risks posed by the best-known endocrine disruptor-BPA. They rely on arguments that ignore scientific research, overstate alleged economic hardships, and contradict wise public policy. Their campaign has sought to advance five fundamental myths about BPA and its dangers. 


\section{The Myth of a Scientific Consensus on Safety}

When the California General Assembly voted down a statewide ban on the use of BPA in children's products like baby bottles, sippy cups, and infant formula containers in 2008, the American Chemistry Council (ACC) issued a press release that misleadingly claimed: "Products targeted by this bill have been affirmed to be safe by government bodies around the world based on the science, most recently by the [Food and Drug Administration]." ${ }^{5}$ This commonly heard refrain from plastics industry activists mischaracterizes the nuanced reports produced by government agencies like the Food and Drug Administration (FDA) and the European Food Safety Agency (EFSA), suggesting a clean bill of health where it is not due. Neither FDA nor EFSA has exonerated the chemical from the concerns about adverse health effects at low doses that have been documented by a robust body of peerreviewed research.

A more accurate description of the state of the science on BPA does not make for such a nice sound-bite. To begin, it would note that FDA and the National Toxicology Program (NTP) have most recently expressed "some concern" about the potential effects of BPA on the brain, behavior, and prostate gland of fetuses, infants, and children. ${ }^{6}$ It would also acknowledge that FDA's January 2010 public health recommendations endorse "reasonable steps to reduce exposure of infants to BPA in the food supply," both by supporting industry efforts to stop producing BPA-containing bottles and sippy cups and by facilitating development of BPA-free linings for formula cans. ${ }^{7}$

BPA manufacturers and the activist groups they sponsor mischaracterize expert panels' judicious work both by claiming that the panels have drawn the simplistic conclusion that BPA is "safe" and by suggesting that the panels' conclusions are uniform. When government agencies empanel experts to weigh in on the safety of particular chemicals, they do not ask the experts to draw broad, policy-dominated conclusions about whether a chemical is "safe." Rather, the experts typically address more complex questions regarding their level of concern about the likelihood of a particular health effect manifesting itself from certain exposure levels for certain groups of individuals. For instance, FDA asked its expert panel to assess whether it should revise the appropriate level of exposure to BPA from food contact applications. ${ }^{8}$ The panel concluded that the evidence was insufficient to support lowering the recommended exposure limit, not that BPA is "safe," as ACC would lead people to believe.' The National Toxicology Program's Center for the Evaluation of Risk to Human Reproduction (NTP/CERHR) asked a slightly different questionwhether BPA affects human reproduction or development. The NTP/CERHR panel expressed concern that low-level exposures to BPA could have negative reproductive and developmental effects. ${ }^{10}$ 
By oversimplifying the conclusions of government-sponsored expert panels, BPA manufacturers and lobbyists seek to sell the myth of scientific consensus to the public and to policymakers who lack the time or inclination to delve into the details of scientific findings on BPA's risks. In doing so, they hope to forestall new regulation. But this mischaracterization is rarely sufficient to carry the debate, so others follow. 


\section{The Good Laboratory Practices Myth}

Mindful that more than 90 percent of Americans are thought to have detectable levels of BPA in their bodies, ${ }^{11} \mathrm{BPA}$ manufacturers and their trade associations have devoted considerable resources to undermining any new evidence that BPA can have adverse health effects at low doses. Because measured concentrations are often low, BPA manufacturers hope to stanch significant regulatory limitations on production or use of the chemical by casting doubt on the science of low-dose health effects.

Industry also knows that the simplest path for an agency facing the prospect of having to regulate a chemical as ubiquitous as BPA without a specific mandate from Congress is to wait until the science is more fully developed. Until then, industry's approach is to seek to undercut scientific studies that demonstrate the danger of their product. Significantly, however, none of the arguments the BPA industry has put forward in opposition to new knowledge about low-dose effects stands up to scrutiny.

The BPA industry's frontal attack on low-dose toxicology seeks to dismiss sound scientific results on the grounds that low-dose effects have only been found in "small-scale experimental studies." ${ }^{12}$ In this view, the only studies that are conducted according to a standard called Good Laboratory Practices (GLP) should be considered relevant to the debate. This argument misperceives the purposes of the GLP standard, which is to specify guidelines for the care of laboratory animals, maintenance of laboratory facilities, personnel requirements, and collection and storage of raw data. ${ }^{13}$ That is, the GLP standard ensures that study results are verifiable and reproducible, regardless of whether the underlying study is properly designed to answer questions relevant to the regulatory debate. The GLP standard is not a measure of whether a study is useful or not, or even if is scientifically rigorous, as BPA supporters claim.

According to a group of 30 academic scientists writing in Environmental Health Perspectives in 2008, "GLP specifies nothing about the quality of the research design, the skills of the technicians, the sensitivity of the assays, or whether the methods employed are current or out-of-date." In fact, conformance with the GLP standard is so immaterial to rating the quality of a particular study that the FDA Science Board, an expert advisory committee, criticized FDA's exclusion of certain BPA studies for failure to meet the GLP standard, since those studies relied on the advanced, updated test procedures that are used at academic labs. ${ }^{14}$ As further evidence that compliance with GLP protocols is not an important factor in determining the validity of a study, expert panels in Japan and Canada do not use GLP as a factor in weighing the relative value of studies. ${ }^{15}$ Industry's arguments about GLP standards are intended as a distraction from the findings of studies that prove inconvenient to manufacturers.
The industry's arguments about GLP

standards are

intended as

a distraction

from the

findings

of studies

that prove

inconvenient to manufacturers. 


\section{The argument}

about ingested quantities

not exceeding

legal limits

fails because

the referenced

legal safety

standards are

not completely

health-

protective.

\section{The Exposure and Metabolism Myths}

When all else fails, BPA manufacturers, users, and their trade associations may concede that BPA poses an inherent hazard as an endocrine-disrupting chemical in the food supply, but then promote myths about exposures and metabolism in an effort to protect specific products. For instance, ACC argues that the amounts of BPA that can migrate from food containers into food "are minute, and well below safety standards set by government regulatory agencies around the world." 16 ACC also argues that "the very small amount of [BPA] that may be ingested by a person during normal daily activities is efficiently converted to biologically inactive metabolites, which are eliminated from the human body within 24 hours." ${ }^{17}$ Neither of these arguments bears scrutiny.

The argument about ingested quantities not exceeding legal limits fails because the referenced legal safety standards are not completely health-protective. That is precisely the point of the debate - that new rules governing BPA are needed to reflect current science. Measured levels of BPA in people's blood may be low, but comparing those levels to "safety standards set by government regulatory agencies around the world" is inappropriate given the basis of the regulatory agencies' findings. ACC cites the EFSA "safe intake level" of $0.05 \mathrm{mg} / \mathrm{kg}$-bw/day as the appropriate reference dose. But ACC fails to note that the level was based on just two multi-generational reproductive toxicity studies in rats; one addressed changes in organ weight in adults and offspring, the other looked at liver effects in adult mice. The reference dose was set in 2006. In 2010, EFSA considered more than 800 other studies of BPA and its potential effects that were published from January 2007 to July 2010. After reviewing this considerably richer range of studies, EFSA echoed the concerns of many other government bodies about BPA's neurobehavioral effects, links to coronary heart disease and reproductive disorders, and potential enhancement of sensitivity of the mammary gland to dimethylbenzanthracene (DMBA)-induced carcinogenesis. Despite these new concerns about adverse health effects related to BPA, EFSA made the controversial decision to retain the $0.05 \mathrm{mg} / \mathrm{kg}$-bw/day reference dose. Thus, ACC's myth of safe exposure levels only holds true to the extent that public health concerns about BPA are limited to organ weights and liver effects.

The myth that BPA is rapidly metabolized to biologically inactive compounds similarly glosses over important policy-relevant facts by ignoring science that does not comport with the myth. ACC points to a single acute-exposure study in which six volunteers were fed one dose of five milligrams of BPA and then monitored for BPA and its metabolites in blood and urine for 96 hours. The study's authors, who have a history of producing reports that seem to exonerate BPA, concluded that the entire dose of BPA was metabolized to a compound called BPA-glucuronide, which is not an endocrine disruptor, and eliminated in urine. ${ }^{18}$ The five milligram acute dose in that study is not representative of our typical exposures to the chemical, which occur almost continuously at much lower levels. To be fair, the same authors found similar results when they dosed another set of six volunteers with a much smaller dose of BPA (25 micrograms). ${ }^{19}$ However, other studies, designed 
to reflect real-world exposure scenarios, have produced different results. For example, researchers interested in determining metabolism of chronic BPA exposure modeled BPA urine concentrations as a function of the time 1,469 participants spent fasting. Their larger dataset was

not consistent with the current consensus that BPA exposures are both rapidly cleared and almost entirely related to food intake. Instead, it appears plausible that there is substantial nonfood exposure, accumulation in body compartments with long elimination times, or both. ${ }^{20}$

So, even granting ACC the point that BPA can be rapidly metabolized to biologically inert compounds, its argument loses relevance because of the many and constant exposure pathways we face. In addition, most of the studies of human BPA metabolism are based on the biological responses of relatively healthy adults. Fetuses, infants, and children have less developed systems for metabolizing environmental toxins and are more susceptible to the developmental impacts of endocrine-disrupting chemicals. Some evidence from animal studies suggests that human fetuses and neonates may not be able to metabolize BPA into an inactive form. ${ }^{21}$ And even in healthy adults, some researchers have discovered that certain body tissues can "de-conjugate" metabolized BPA, making it active again. ${ }^{22}$

A closer look at the exposure and metabolism myths reveals a bigger problem: the dubious hypothesis that low doses of BPA always induce fewer adverse consequences than high doses. While the standard assumption with many toxic chemicals is that physiological reactions to the chemicals have a direct and "monotonic" relationship to exposures (i.e., as exposure to a chemical increases, so does the adverse health outcome), the endocrine system does not always work that way. In fact, researchers have found "nonmonotonic dose response functions" when they have exposed pituitary, prostate cancer, and other cells to BPA. ${ }^{23}$ It is also worth noting that the estrogen receptors that BPA can bind to and activate are normally activated by minute levels of natural hormones - at levels measured in picograms and nanograms per milliliter of blood. Numerous studies show human blood levels of BPA in that range. ${ }^{24}$

As with the rest of the scientific myths propounded by BPA manufacturers and their activist trade associations, the claims about the safety of low-level exposure to BPA ignore significant and legitimate public health concerns that arise from ample scientific evidence. 


\section{Economic Myths}

Particularly during difficult economic times, industry has developed a practice of hiding behind the specter of financial ruin at the hands of insensitive bureaucrats in order to stem the tide of regulation. The companies that manufacture BPA and their customers who use it to formulate plastics and epoxy resins have developed a slightly more nuanced-but much more distressing — approach, touting BPA's allegedly crucial role in protecting the food supply. As the North American Metal Packaging Alliance (NAMPA) readily points out, BPA-based epoxy can linings have the important characteristics of being able to withstand the intense heat that companies use to kill bacteria in certain canned goods, being easily manipulated, extending shelf life, and not imparting off-flavors in food—all at a relatively low cost. They often intimate that restrictions on BPA in can linings could lead to spoiled or dangerous food. For example, when interviewed for a 2010 Washington Post article on BPA alternatives, NAMPA's chairman noted that "there hasn't been a case of food-borne illness resulting from a failure of metal packaging since the industry began using BPA in its linings more than 30 years ago." 25

The objective of such rhetoric is to suggest that policymakers must choose between BPA and an unsafe food supply. The facts suggest otherwise. Intense public pressure to abandon BPA in products like water bottles and canned foods has prompted many companies to seek out alternative solutions. State-level bans on the sale of BPA-containing children's products, along with Japan's limitations on BPA in can linings, are also promoting development of BPA alternatives. With respect to can linings, it appears that reliable, durable alternatives exist for most foods. A polyester compound has been identified as suitable for a wide range of canning applications, ${ }^{26}$ and plant-derived "oleoresins" have also been adopted. ${ }^{27}$ Highacid foods like tomatoes present a challenge because they can break down the BPA-free oleoresin linings, reducing shelf life, but researchers are working on solutions. With the development of BPA-free products, a slight rift has developed in the messages from the likes of ACC and NAMPA, on the one side, and downstream consumer goods companies, on the other. Companies like Nalgene and Eden Foods, who cater to health-conscious consumers, market BPA-free products (water bottles and canned foods, respectively) and, unlike the chemical industry trade associations, they do not make claims about the chemical's safety in the food supply.

Replacement costs are always a sticking point for new technologies, but alternatives to BPA have not proven to be as prohibitively costly as manufacturers and trade associations suggest. In fact, their estimates for replacing can linings ignore market factors that contribute to reducing costs of replacement technologies, especially the effect of economies of scale. ${ }^{28}$ The Japanese economic analysis for the phase-out of school cafeteria tableware containing BPA was 127 yen per student per year, or approximately $\$ 1.10$ in 2007 dollars. ${ }^{29}$ One company replaced its canned beans' BPA-lined cans with a BPA-free alternative in 1999 and found that using the BPA-free lining added just three to five cents to the retail prices. ${ }^{30}$ 
When regulation of a toxic chemical might increase production costs, industry groups have consistently overstated cost estimates to challenge regulations. For example, automakers argued that there were no suitable air pollution control technologies to control emissions of smog-forming nitrogen oxides, and acid-rain-producing sulfur dioxide from cars, and that fuel economy would suffer if existing technologies were implemented. But the incentives created by regulation led automakers to introduce catalytic converters, which resulted in substantial reductions in air pollution while increasing fuel economy at the same time. ${ }^{31}$ Regulatory agencies rarely conduct retrospective analyses to verify the real world costs of regulation. In the rare cases in which such analyses have been conducted, the ultimate compliance costs have often been proven to be only a fraction of what was projected before a regulation was implemented. ${ }^{32}$

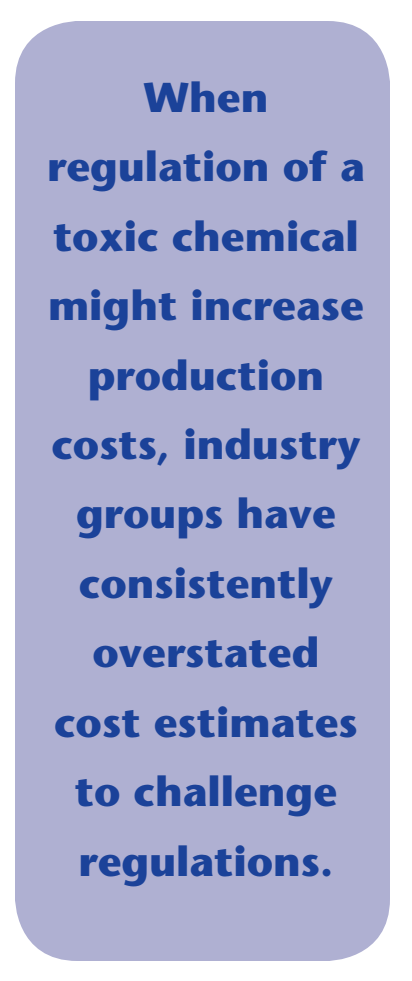




BPA supporters'
real goal in
presenting
the myth of
"patchwork
regulation," is
not to promote
federal
regulation,
but to focus
the regulatory
debate inside
the D.C.
Beltway, where
the plastics
industry rightly
believes it has
the best chance
of beating
back stronger
regulation.

\section{The Myth of the Patchwork of Regulations}

Through tireless efforts and a web-savvy campaign, a grassroots coalition of breastcancer-prevention advocates, environmentalists, concerned parents, and their allies have successfully lobbied for restrictions on BPA-containing products in Connecticut, Maryland, Massachusetts, Minnesota, Vermont, Washington, Wisconsin, several counties in New York, and the City of Chicago. ${ }^{33}$ Their success at the state and local level has prompted the plastics industry to resort to a myth of a slightly different nature but no greater legitimacy than the myths discussed above: they decry an allegedly incomprehensible "patchwork of regulation." As tobacco and automobile manufacturers did in their own battles to avoid regulation, the BPA-manufacturing industry complains that lack of uniformity in state-level regulations increases the costs of producing, distributing, and marketing their products. They argue that uniform federal regulation provides a more predictable and economical business environment.

Federal regulation of toxic substances can certainly produce significant benefits by protecting public health. But the vast majority of federal environmental laws establish a "floor" and not a "ceiling," allowing the states to go beyond minimum national standards to protect their citizens. In fact, state and local governments have often responded more quickly to emerging threats, serving as "laboratories of democracy," for the federal system. State-level toxics-control programs have often preceded federal programs with great success.

One example in particular is California's regulation of polybrominated diphenyl ethers (PBDEs). In 2003, California enacted a ban on penta- and octa-brominated diphenyl ether, two widely distributed PBDEs. The ban took effect in 2008. ${ }^{34}$ At the time California banned the chemicals, the state of the science on PBDEs paralleled the current knowledge about BPA: scientists had evidence of widespread human and environmental exposure, they had observed disruption of normal hormonal processes in lab animals, but they continued to debate exactly what levels might be deemed "safe." But because substitutes were readily available, the only company to produce the chemicals in the U.S. began to phase out production within three months of enactment of the California ban. ${ }^{35}$

Federal action to control exposures to PBDEs lagged behind, but is better informed because of the California ban. A year and a half after the Great Lakes Chemical Corporation voluntarily stopped production of the two PBDEs banned in California, EPA finally completed a rulemaking under TSCA that simply established a requirement for companies to notify the agency if they want to produce or import the chemicals. ${ }^{36}$ In 2010 , in response to evidence that the chemicals are still being found-perhaps even at elevated levels - in people's bodies and in the environment despite the phase-out of production and importation, EPA published a Chemical Action Plan for a broad class of PBDEs. ${ }^{37}$ The plan shows that EPA has developed a better agenda for addressing these chemicals' risks because state-level policies served as tests of potential regulatory techniques. 
Compliance with heterogeneous state and local regulations is rarely too complicated for sophisticated product manufacturers and marketers. History shows that manufacturers can work around inconsistent regulatory requirements, in the rare instances where such a "patchwork" exists. For example, California's Proposition 65 sets labeling requirements to inform consumers when products contain chemicals known to cause cancer, birth defects, or other reproductive harm. The law only applies in California, but manufacturers have successfully created labels or new product formulations without major disruptions. ${ }^{38}$

BPA supporters' real goal in presenting the myth of "patchwork regulation," is not to promote federal regulation, but to focus the regulatory debate inside the D.C. Beltway, where the plastics industry rightly believes it has the best chance of beating back stronger regulation. In Washington, BPA industry lobbyists and campaign contributors can focus on a smaller number of decisionmakers. Moreover, federal regulations are subject to numerous procedural and analytical requirements, providing BPA manufacturers with multiple opportunities to delay the process and introduce new and sometimes misleading information into regulatory proceedings. ${ }^{39}$

By contrast, each of these factors makes it more difficult for local and grassroots groups to engage effectively in the federal rulemaking process. While they have relationships with local politicians and state legislatures, they often have only limited contact and influence with national politicians, who interact with a far greater number of constituents, donors, and stakeholders than their local counterparts. Funding, distance, and personnel constraints also limit the advocates' ability to participate in agency deliberations, including public hearings and meetings. For example, it is expensive, often prohibitively so, for grassroots activists to fly to Washington, D.C., to attend a public meeting or hearing. It is even more difficult for grassroots activists to meet with agency staff face-to-face. The volume and technical detail involved in regulatory analyses raises the cost of participation in the federal regulatory process, and causes some grassroots and public health advocacy groups to drop out of the process. ${ }^{40}$ Preserving the availability of state- and local-level toxics regulation thus preserves the possibility of effective participation by as many voices as possible in the determination of how to control dangerous chemicals. 


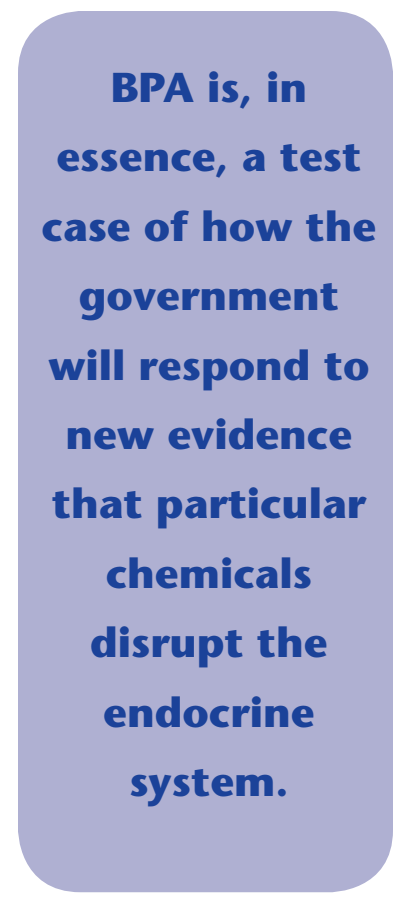

Myths and Truths in the Debate Over BPA Regulation 
Federal toxic control laws are severely outdated, and leave significant room for legislative improvement. Congress could improve the federal approach to toxics regulations by affirmatively empowering agencies like the EPA, FDA, CPSC and OSHA to regulate endocrine-disrupting compounds. Although the statutes in place do not preclude these agencies from moving forward on modernizing their approach to endocrine disruptors, the agencies have been slow to adapt to new science about risks from toxic substances. One significant hurdle to regulating endocrine disruptors is a failure to adopt new risk assessment guidelines that account for low-dose effects by encouraging exploration of nonmonotonic dose-response relationships. EPA, for example, took more than ten years to evaluate and adapt test procedures just to screen for endocrine disruptors. ${ }^{42}$ A 2007 National Academy of Sciences report described a vision for modernized toxics testing, but contemplated a 20 to 30-year timeline for its implementation. ${ }^{43}$

EPA and other regulatory agencies should use caution when considering alternatives to BPA. It is important that any replacement for BPA not pose the same - or even more serious public health hazards. Based on what we know now about endocrine-disrupting compounds, EPA should take advantage of new screening tools. One particularly useful tool would be EPA's Distributed Structure-Searchable Toxicity Database Network, which allows researchers and others to screen chemicals for potential toxicity based on similar chemical structures. 


\section{Conclusion}

Scientists and government panels have amassed enough evidence that BPA is a potentially harmful endocrine disruptor to move forward with controlling exposure from food contact applications. As scientists develop a fuller picture of other exposure pathways (e.g., transdermal exposure from thermal paper), agencies should adopt a precautionary approach to limiting exposures to BPA. At the very least, the NTP and EPA should revise outdated exposure limits for BPA, by expanding the focus of their risk assessments to a broad range of potential adverse health effects. The federal government should also encourage the adoption of state and local regulations aimed at managing risks posed by BPA and other endocrine-disrupting chemicals. As federal officials gather the evidence they need to meet the high burdens of TSCA, the FDCA, the OSH Act, and other statutes, state and local regulation can provide some measure of protection to the public while also supplying federal agencies with evidence for or against different regulatory options.

The plastics industry is following a well-worn strategy to delay regulation of BPA. The strategy relies on efforts to generate the perception that BPA does not pose a public hazard, coupled with efforts to contain regulatory action at the federal level, where the industry can influence the regulatory process most effectively. Agencies and advocates should be accustomed to this pattern of industry distortion and should filter it out of the public dialogue. 


\section{Endnotes}

1 Sarah Vogel, Battles Over Bisphenol A (Apr. 16, 2008), at http://www.defendingscience.org/case studies/BattlesOver-Bisphenol-A.cfm (accessed Apr. 28, 2011); Theo Colburn, Dianne Dumanoski, and John Peterson Myers, Our Stolen Future 122-41 (Penguin Group, 1997).

2 Calafat et al., Urinary Concentrations of Bisphenol $A$ and 4-Nonylphenol in a Human Reference Population, 113 ENv. Health Perspectives 391 (Apr. 2005).

3 Thomas O. McGarity \& Wendy E. Wagner, Bending Science: How Special Interests Corrupt Public Heatth Research 183-187, 135 (Harvard Univ. Press, 2008); David Michaels, Doubt is Their Product: How Industry's Assault on Science Threatens Your Health 48, 53 (Oxford Univ. Press, 2008); Thomas McGarity \& Ruth Ruttenberg, Counting the Cost of Health, Safety, and Environmental Regulation, 80 Tex. L. Rev. 1997 (June 2002) [hereinafter McGarity \& Ruttenberg, Counting the Cost].

4 See, e.g., Jon Entine, BPA: DOA? 27 Env. Forum 24 (Nov./Dec. 2010).

5 American Chemistry Council, Press Release: ACC Applauds California's Decision to not Ban Food-Contact Products Containing Bisphenol A (Aug. 30, 2008), available at http:// www.americanchemistry.com $/ \mathrm{s} \mathrm{acc} / \mathrm{sec}$ news article. asp? $\mathrm{CID}=206 \& D I D=7923$ (accessed Apr. 28, 2011).

6 U.S. Food and Drug Administration, Draft Assessment of Bisphenol A for Use in Food Contact Applications 2 (2008), available at http://www.fda.gov/ohrms/dockets/ac/08/ briefing/2008-0038b1 0102 FDA $\% 20 \mathrm{BPA} \% 20$ Draft $\% 20$ Assessment.pdf (accessed Apr. 28, 2011) [hereinafter 2008 FDA Draft Assessment]; NATIONAL Toxicology Program, U.S. Dept. of health and Human SERVICES, NTP-CERHR Monograph on the Potential Human Reproductive and Developmental Effects of Bisphenol $A$, at vii (Sept. 2008), available at http://cerhr.niehs.nih.gov/ evals/bisphenol/bisphenol.pdf (accessed Apr. 28, 2011) [hereinafter 2008 NTP/CERHR Monograph].

7 U.S. Food and Drug Administration, Update on Bisphenol A for Use in Food Contact Applications (Jan. 2010), at http://www.fda.gov/downloads/NewsEvents/ PublicHealthFocus/UCM197778.pdf (accessed Apr. 28, 2011).

82008 FDA Draft Assessment, supra n.6, at 2.

$9 \quad I d$.

10 2008 NTP/CERHR Monograph, supra n.6.

11 Antonia M. Calafat et al., Exposure of the U.S. Population to Bisphenol A and 4-tertiary-Octylphenol: 2003-2004, 115 ENv. Health Perspectives 39 (Jan. 2008); Antonia M. Calafat et al., Urinary Concentrations of Bisphenol $A$ and 4-Nonylphenol in a Human Reference Population, 113 Env. Health Perspectives 391 (Apr. 2005).
12 American Chemistry Council, Comments on Documents Prepared by FDA's Center for Food Safety and Applied Nutrition Regarding FDA's Continuing Assessment of Bisphenol A, 3-4 (June 4,2010 ) available at http://www.regulations.gov Docket Number FDA-2010-N-0100.0014.1 (accessed Apr. 28, 2011).

13 John Peterson Myers et al., Why Public Health Agencies Cannot Depend on Good Laboratory Practices as a Criterion for Selecting Data: The Case of Bisphenol A, 117 Env. Health Perspectives 309, 310 (March 2009).

14 fDA Science Board Subcommittee on Bisphenol A, Scientific Peer-Review of the Draft Assessment of Bisphenol A for Use in food Contact Applications, 6 (2008) available at http://www.fda.gov/ohrms/dockets/ ac/08/briefing/2008-4386b1-05.pdf (accessed Apr. 28, 2011).

15 See Environment Canada, Health Canada, Screening Assessment for the Challenge, Phenol, 4,4'-(1-Methylethylidene)Bis- (Bisphenol A) 73 (2008) available at http://ec.gc.ca/substances/ese/ eng/challenge/batch2/batch2 80-05-7 en.pdf (accessed Apr. 28, 2011); see also, NATional Institute of Advanced Industrial Science and Technology (Japan), Risk assessment Document Series 4, Bisphenol A 13 (2007) available at http://unit.aist.go.jp/riss/

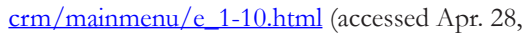
2011) [hereinafter AIST, Risk Assessment Document, Bisphenol A].

16 American Chemistry Council, Bisphenol A Myths: BPA From Food Containers is Harmful, at http://bisphenol-a.org/ about/bpa-myths/bpa-food-containers.html (accessed Apr. 28, 2011).

17 American Chemistry Council, Bisphenol A Myths: BPA Accumulates in the Human Body, at http://bisphenol-a.org/ about/bpa-myths/bpa-accumulates.html (accessed Apr. $28,2011)$.

18 Wolfgang Völkel et al., Metabolism and Kinetics of Bisphenol A in Humans at Low Doses Following Oral Administration, 15 Chem. Res. toxicol. 1281 (Oct. 2002); see also, Susanne Rust, New plastic chemical study linked to industry, CALIFORNIA WATCH (Apr. 28, 2011), at http://californiawatch. org/dailyreport/new-plastic-chemical-study-linkedindustry-10042 (accessed Apr. 28, 2011).

19 Wolfgang Völkel et al., Quantitation of bisphenol $A$ and bisphenol A glucuronide in biological samples by high performance liquid chromatography-tandem mass spectrometry, 33 DRUG Metab. Dispos. 1748 (Nov. 2005).

20 Richard A. Stahlhut et al., Bisphenol A Data in NHANES Suggest Longer than Expected Half-Life, Substantial Nonfood Exposure, or Both, 117 Env. Health Persp. 784 (May 2009). 
21 See Vandenberg et al., BPA and the Great Divide, 30 Endocrine ReVIEWs 75, at 84 (Jan. 2009).

22 Id.

23 See id, at 79.

24 See Welshons et al., Large Effects from Small Exposures. III. Endocrine Mechanisms Mediating Effects of Bisphenol A at Levels of Human Exposure, 147 ENDOCRINOLOGY s56, at s62 (Supp. 2006).

25 Lyndsey Layton, Alternatives to BPA containers not easy for U.S. foodmakers to find, WASH. POST (Feb. 23, 2010), available at http://www.washingtonpost.com/wp-dyn/content/ article/2010/02/22/AR2010022204830.html (accessed Apr. 28, 2011).

26 Rory Harrington, Bisphenol A-free polymer coating touted as alternative to epoxy can lining, FOOD PRODUCTION DAILY (Sept. 17, 2010), available at http://www. foodproductiondaily.com/Packaging/Bisphenol-A-freepolymer-coating-touted-as-alternative-to-epoxy-can-lining (accessed Apr. 28, 2011).

27 Melody Voith, Can Conundrum: Chemists come up short in attempts to remove bisphenol $A$ from food can liners, CHEM. \& ENG. News (July 20, 2009), available at http://pubs.acs. org/cen/business/87/8729bus2.html (accessed Apr. 28, 2011) [hereinafter Voith, Can Conundrum].

28 Economic Policy Institute, Briefing Paper: Cost of Complying with Environmental Regulations Almost Always Less Than Advertised 10 (1997) available at http://www.epi.org/ page/-/old/briefingpapers/bp69.pdf (accessed Apr. 28, 2011)

29 AIST, Risk Assessment Document: Bisphenol A, supra n. 15 , at 14 .

30 Voith, Can Conundrum, supra n.27.

31 McGarity \& Ruttenberg, Counting the Costs, supra n.3, at 2024.

32 McGarity \& Ruttenberg, Counting the Costs, supra n.3, at 2017.

33 Safer Chemicals Healthy Families/Natural Resources Defense Council, Congressional Action Needed on a Chemical of High Concern: Bisphenol A (BPA), at http://www. saferchemicals.org/PDF/resources/bpa factsheet.pdf (accessed Apr. 1, 2011)

34 Jennifer Lee, California to Ban Chemicals Used as Flame Retardants, New York Times (Aug. 10, 2003) available at http://www.nytimes.com/2003/08/10/us/ california-to-ban-chemicals-used-as-flame-retardants. html?pagewanted =all (accessed Apr. 28, 2011).

35 U.S. Env. Protection Agency, Polybrominated diphenylethers (PBDEs) Significant New Use Rule (SNUR) Questions and Answers, at http://www.epa.gov/oppt/pbde/pubs/qanda. $\underline{\mathrm{htm}}$ (accessed Apr. 28, 2011).

36 U.S. Env. Protection Agency, Certain Polybrominated Diphenylethers; Significant New Use Rule, 71 Fed. Reg. 34,015 (Jun. 13, 2006).
37 U.S. Env. Protection Agency, Polybrominated Diphenyl Ethers (PBDEs) Action Plan Summary, at http://www.epa. gov/opptintr/existingchemicals/pubs/actionplans/pbde.

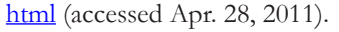

38 See Percival, Schroeder, Miller, and Leape, 4 Environmental Regulation: Law, Science, and Policy 478 (Aspen Pub., 2003).

39 See Data Quality Act, \515 Consolidated Appropriations Act (2001), Pub. L. No. 106-554; Regulatory Flexibility Act, 5 U.S.C. IS 601-612; Office of the President, Executive Order 12,866, Regulatory Planning and Review, 58 Fed. Reg. 51,738 (Oct. 4, 1993).

40 Wendy Wagner, Administrative Law, Filter Failure, and Information Capture, 59 DukE L. J. 1321, 1384 (Apr. 2010).

$41 \quad 15$ U.S.C. \$S 2604(b)(4), 2607 (a)(3)(A)(ii)(I).

42 U.S. Env. Protection Agency, Endocrine Disruptor Screening Program History, at http://www.epa.gov/endo/ pubs/edspoverview/primer.htm (accessed Apr. 28, 2011).

43 National Research Council, National Academy of Sciences, Toxicity Testing in the $21^{\text {st }}$ Century, A Vision AND STRATEGy 167 (2007). 


\section{About the Authors}

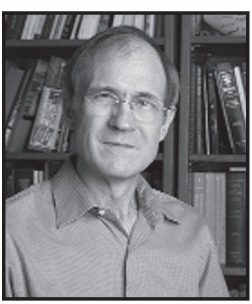

Thomas O. McGarity holds the Joe R. and Teresa Lozano Long Endowed Chair in Administrative Law at the University of Texas in Austin. He is a member of the Board of Directors of the Center for Progressive Reform, and the immediate past president of the organization. Professor McGarity has published widely in the areas of regulatory law and policy. His recent scholarship includes Bending Science: How Special Interests Corrupt Public Health Research (Harvard Univ. Press), which earned him and co-author Wendy Wagner (also a CPR Member Scholar) the prestigious Hamilton Book Author Award.

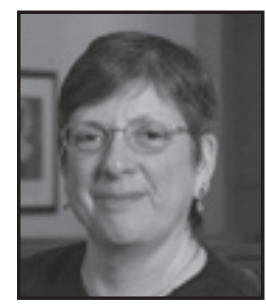

Rena Steinzor is the President of the Center for Progressive Reform and a Professor of Law at the University of Maryland School of Law. Professor Steinzor has written extensively on efforts to reinvent environmental regulation in the United States and the use and misuse of science in environmental policy making. Among her publications include a book titled Mother Earth and Uncle Sam: How Pollution and Hollow Government Hurt Our Kids and a wide range of articles on administrative, constitutional, and environmental law. Professor Steinzor was staff counsel to the U.S. House of Representatives' Energy and Commerce Committee with primary jurisdictions over federal laws regulating hazardous substances and was the partner in charge of the environmental law practice at Spiegel and McDiarmid.

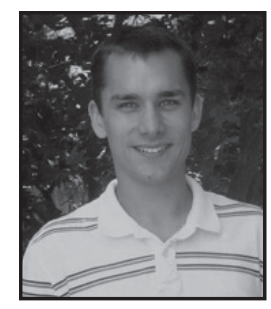

Matthew Shudtz is a Senior Policy Analyst at the Center for Progressive Reform, providing research, drafting, coordination and other staff assistance to CPR's Clean Science and Corporate Accountability Issue Groups. Prior to joining CPR, Mr. Shudtz worked as a legal intern for the Natural Resources Defense Council and as a legal/legislative intern for the Chesapeake Bay Foundation.

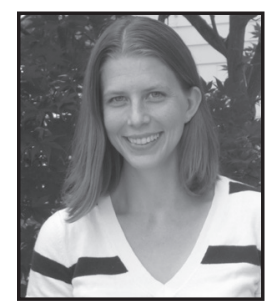

Lena Pons is a Policy Analyst at the Center for Progressive Reform, with experience in regulatory agencies and regulatory process issues. Prior to joining CPR, she worked on regulatory policy matters for four years at Public Citizen, covering transportation safety and energy policy and worker protections. She also worked on regulatory process issues involving the Office of Information and Regulatory Affairs of the Office of Management and Budget. Ms. Pons graduated from the University of Wisconsin-Madison with a B.S. in chemistry 


\section{CPR's Clean Science Work}

Vigorous implementation and enforcement of statutory environmental, health, and safety standards depends on sound judgments based on clean science. CPR's staff and scholars have spent years researching federal science policy issues and have developed solutions to a wide range of problems that strain federal agencies' ability to create effective regulatory programs.

\section{Other work by CPR scholars:}

Rescuing Science from Politics: Regulation and the Distortion of Public Research (Cambridge Univ. Press, 2008)

Edited by Rena Steinzor and Wendy Wagner

With contributions from CPR Member Scholars David Adelman, John Applegate, Carl Cranor, Holly Doremus, Donald Hornstein, Thomas McGarity, Sidney Shapiro, and Katherine Squibb, the book begins by establishing non-controversial principles of good scientific practice. These principles then serve as the benchmark against which each chapter author compares how science is misused in a specific regulatory setting and assist in isolating problems in the integration of science by the regulatory process.

Saving Science from Politics: Nine Essential Reforms of the Legal System By Rena Steinzor, Wendy Wagner, and Matthew Shudtz $<<$ http://www.progressivereform.org/articles/SavingScience805.pdf $>>$

As its title suggests, the white paper proposes a series of practical reforms, including requiring that studies submitted to federal agencies be accompanied by disclosure of the amount of control sponsors had over the design and publication of research, ending the current practice of overly broad trade-secret claims intended to prevent disclosure of important research to the public, and strengthening the legal requirement that companies disclose information they have about the risks their products pose to public health and the environment.

EPA's Integrated Risk Information System

$<<$ http://www.progressivereform.org/iris.cfm $>>$

CPR has published an ongoing series of white papers about EPA's premier toxicological database- the Integrated Risk Information System (IRIS). The chemical-specific risk assessments developed for IRIS are the starting point for regulations under numerous environmental laws, including the Safe Drinking Water Act and Superfund law. 
Notes: 
To see more of CPR's work or to contribute, visit CPR's website at www.progressivereform.org.

455 Massachusetts Avenue, NW

\# 150-513

Washington, DC 20001

202-747-0698 (phone/fax)

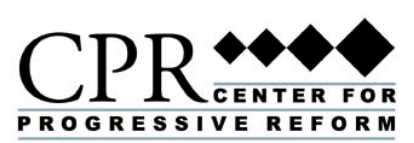

RETURN UNDELIVERABLES TO:

Center for Progressive Reform 455 Massachusetts Avenue, NW \# 150-513

Washington, DC 20001 